\title{
Burulma Düzensizliğinin Betonarme Yapı Davranışına Etkileri
}

\author{
Hakan ERDEM ${ }^{* 1}$ \\ ${ }^{1} N i g ̆$ de Üniversitesi, Mühendislik Fakültesi, Inşaat Mühendisliği Bölümü, Niğde
}

Geliş tarihi: 10.02.2016 Kabul tarihi: 17.03 .2016

\section{Özet}

Yapıların taşıyıcı sistemlerinin depreme dayanıklı taşıyıcı sistem seçimi ilkelerine uygun seçilmemesi yapının davranışını olumsuz etkiler. Yapıların kütle ve rijitlik merkezlerinin çakıştırılmaması da burulma düzensizliğine sebep olur. Bu durumda olan yapıların bazı parametreleri, burulma düzensizliğinin etkilerini görmek için incelenecektir. Hesaplamalarda kolon boyutları değiștirilerek farklı eksantirisiteye ve rijitliklere sahip taşıyıcı sistemler oluşturulmuș ve İdeCAD programı kullanılarak yapılar modellenmiş ve analiz edilmiştir. Elde edilen sonuçlar yapısal düzensizlikler, yapı ağırlı̆̆ı, birinci periyotlar ve taban kesme kuvvetleri için karşılaştırılmıştır.

Anahtar Kelimeler: Betonarme yapı, Deprem, Burulma düzensizliği, Yapısal davranış

\section{Effects of Torsional Irregularity on Reinforced Concrete Behaviour}

\begin{abstract}
If skeletal system is not selected according to the principles of earthquake resistant skeletal system selection, it negatively affects the behavior of the structure. Torsional irregularity occurs when the mass and stiffness center of the structure isn't same. Some parameters of the structure, which in the case will be examined to see the effects of torsional irregularity. In the calculations, skeletal systems having different eccentricity and rigidity by changing column dimensions were selected, modeled and analyzed using IdeCAD program. Structural irregularities, structure weight, first period and base shear forces are compared for the results obtained.
\end{abstract}

Keywords: Reinforced concrete structure, Earthquake, Torsional irregularity, Structural behaviour

\footnotetext{
* Yazışmaların yapılacağı yazar: Hakan ERDEM, Niğde Üniversitesi, Mühendislik Fakültesi, İnşaat Mühendisliği Bölümü, Niğde, herdem@nigde.edu.tr
} 


\section{GIiRIŞ}

Betonarme yapıların taşıyıcı sistemleri estetik, emniyet ve ekonomiyi gözetecek biçimde tasarlanır. Deprem Bölgelerinde Yapılacak Binalar Hakkında Yönetmelik'te (DBYBHY) bahsedilen depreme dayanıklı yapı tasarımı ilkeleri de taşıyıcı sistem seçiminde dikkate alınır [1]. Doğru taşıyıcı sistem seçimi yapılmaması ya da yapılamaması durumunda yapının davranışı olumsuz etkilenir. DBYBHY'de planda ve düşey doğrultuda düzensizlikler kontrol edilerek yapının davranışı düzeltilmeye çalışılır. Ancak, bazı yapıların mimari projelerinin uygun olmaması ya da taşıyıcı sistem seçim ilkelerine yeterince sahip olmayan tasarımcı hataları nedeniyle doğru bir taşıyıcı sistem seçimi yapılamayabilir. Özellikle kütle ve rijitlik merkezinin çakıştırılamamış olması durumunda yapıda burulma düzensizliği oluşur. $\mathrm{Bu}$ tür yapıların depremde diğer yapılara göre daha fazla hasar gördükleri gözlenmiştir.

Burulma düzensizliği ve bu düzensizliğin yap1 ve davranışı üzerine bazı çalışmalar yapılmıştır. Boğa [2] çok katlı yapılarda burulma düzensizliğinin etkilerini incelemiştir. Özmen [3-7] çok katlı yapılarda burulma düzensizliklerini, rijitlik dağılımının burulma düzensizliğine etkilerini ve deprem yönetmeliklerindeki burulma düzensizliği koşullarını incelemiştir. Livaoğlu [8] yapıların deprem hesabında burulma düzensizliğini ve kullanılan hesap yöntemlerinin etkinliğini, Uçar ve Merter [9] taşıyıcı sistemlerde perde yerleşiminin binaların depremdeki davranışına etkisini, Doğan ve $\operatorname{Er}$ [10] hareketli yük dağılımın burulma düzensizliğine etkisini incelemiştir. Sandıkçı [11] ise yumuşak kat düzensizliği ile burulma düzensizliği arasındaki ilişkiyi araştırmıştır.

$\mathrm{Bu}$ çalışmada taşıyıcı sistemi oluşturan düşey taşıyıcı eleman kolonların simetrik yerleştirilmemesi ve yapının kütle merkezi ile çakışmaması durumunda olan betonarme yapılarda burulma düzensizliğinin yapı davranışına etkileri incelenecektir. Kütle ve rijitlik merkezinin çakışmamasının sonucu olarak bir eksantrisite oluşacak ve buda yapıda burulmanın oluşmasına neden olacaktır. Önce kütle ve rijitlik merkezi çakışan bir yapı alınmış, daha sonra seçilen bir kolon boyutları değiştirilerek farklı durumlar oluşturulmuş ve İdeCAD paket programı ile farklı taşıyıcı sisteme sahip aynı yapının analizi yapılmıştır. Elde edilen düzensizlikler, yap1 ağırlıkları, birinci periyotlar, spektrum katsayıları, taban kesme kuvvetleri karşılaştırılmıştır.

\section{YAPISAL DÜZENSİZIIKLER}

\subsection{Düzensiz Binalar}

Depreme karşı davranışlarındaki olumsuzluklar nedeni ile tasarımından ve yapımından kaçınılması gereken düzensiz binaların tanımlanması ile ilgili olarak, planda ve düşey doğrultuda düzensizlik meydana getiren durumlar ve bunlarla ilgili koşullar DBYBHY'de verilmiştir.

\subsection{Planda Düzensizlikler}

Plandaki düzensizlikler, A1-Burulma Düzensizliği, A2-Döşeme Süreksizlikleri ve A3-Planda Çıkıntılar Bulunması durumlarıdır.

\subsubsection{Burulma Düzensizliği}

Birbirine dik iki deprem doğrultusunun herhangi biri için, herhangi bir katta en büyük göreli kat ötelemesinin $\left(\Delta_{\text {imax }}\right)$, o katta aynı doğrultudaki ortalama göreli ötelemeye oranını $\left(\Delta_{\text {iort }}\right)$ ifade eden burulma düzensizliği katsayısı $\eta_{\mathrm{bi}}$ 'nin 1,2'den büyük olması durumudur. Göreli kat ötelemelerinin hesabında, $\pm \% 5$ ek dışmerkezlik etkileri de göz önüne alınarak, Eşitlik 1'e göre yapılır.

$\eta_{b i}=\frac{\Delta_{i_{\max }}}{\Delta_{i_{\text {ort }}}}>1,2$

\subsubsection{Döșeme Süreksizlikleri}

Herhangi bir kattaki döşemede, merdiven ve asansör boşlukları dahil, boşluk alanları toplamının $\left(A_{b}\right)$ kat brüt alanının $(A)$ 1/3'ünden fazla olması, 
deprem yüklerinin düşey taşıyıcı sistem elemanlarına güvenle aktarılabilmesini güçleştiren yerel döşeme boşluklarının bulunması, döşemenin düzlem içi rijitlik ve dayanımında ani azalmaların olması durumudur.

$$
\frac{A_{b}}{A}>\frac{1}{3}
$$

\subsubsection{Planda Çıkıntılar Bulunması}

Bina kat planlarında çıkıntı yapan kısımların $\left(a_{\text {clkntt }}\right)$ birbirine dik iki doğrultudaki boyutlarının her ikisinin de, binanın o katının aynı doğrultulardaki toplam plan boyutlarının $(L)$ $\% 20$ 'sinden daha büyük olması durumudur.

$a_{\text {çıkntı }}>0,2 L$

\subsection{Düșey Doğrultuda Düzensizlikler}

Düşey doğrultudaki düzensizlikler, B1-Komşu Katlar Arası Dayanım Düzensizliği (Zayıf Kat), B2-Komşu Katlar Arası Rijitlik Düzensizliği (Yumuşak Kat) ve B3-Taşıyıcı Sistemin Düşey Elemanlarının Süreksizliği olarak tanımlanmıştır.

\subsubsection{Komşu Katlar Arası Dayanım Düzensizliği}

Betonarme binalarda, birbirine dik iki deprem doğrultusunun herhangi birinde, herhangi bir kattaki etkili kesme alanının $\left(\Sigma A_{g}\right)_{i}$, bir üst kattaki etkili kesme alanına $\left(\Sigma A_{g}\right)_{i+1}$, oranı olarak tanımlanan dayanım düzensizliği katsayısı $\eta_{\mathrm{ci}}$ 'nin 0,80'den küçük olması durumudur.

$$
\begin{aligned}
& \eta_{c i}=\frac{\left(\sum A_{e}\right)_{i}}{\left(\sum A_{e}\right)_{i+1}}<0,80 \\
& \sum A_{e}=\sum A_{w}+\sum A_{g}+0,15 \sum A_{k}
\end{aligned}
$$

\subsubsection{Komşu Katlar Arası Rijitlik Düzensizliği (Yumuşak Kat)}

Birbirine dik iki deprem doğrultusunun herhangi biri için, herhangi bir i'inci kattaki ortalama göreli kat ötelemesinin kat yüksekliğine oranının $\left(\Delta_{\mathrm{i}} / \mathrm{h}_{\mathrm{i}}\right)_{\text {ort }}$ bir üst $\left(\Delta_{\mathrm{i}+1} / \mathrm{h}_{\mathrm{i}+1}\right)_{\text {ort }}$ veya bir alt kattaki $\left(\Delta_{\mathrm{i}-1} / \mathrm{h}_{\mathrm{i}-1}\right)_{\text {ort }}$ ortalama göreli kat ötelemesinin kat yüksekliğine oranına bölünmesi ile tanımlanan rijitlik düzensizliği katsayısı $\eta_{\mathrm{ki}}$ 'nin 2 den fazla olması durumudur. Göreli kat ötelemelerinin hesabı, $\pm \% 5$ ek dışmerkezlik etkileri de gözönüne alınarak yapilır.

$\eta_{k i}=\frac{\left(\frac{\Delta_{i}}{h_{i}}\right)_{o r t}}{\left(\frac{\Delta_{i+1}}{h_{i+1}}\right)_{o r t}}>2$

$\eta_{k i}=\frac{\left(\frac{\Delta_{i}}{h_{i}}\right)_{o r t}}{\left(\frac{\Delta_{i-1}}{h_{i-1}}\right)_{o r t}}>2$

\subsubsection{Taşıyıcı Sistemin Düşey Elemanlarının Süreksizliği}

Taşıyıcı sistemin düşey elemanlarının (kolon veya perdelerin) bazı katlarda kaldırılarak kirişılerin veya guseli kolonların üstüne veya ucuna oturtulması, ya da üst kattaki perdelerin altta kolonlara oturtulması durumudur.

\section{SAYISAL UYGULAMA}

$\mathrm{Bu}$ çalışmada, yönetmeliklerdeki burulma düzensizliğinin yapıların davranışı üzerinde etkileri yapının $\mathrm{x}$ ve $\mathrm{y}$ doğrultularında birinci periyotlar1, taban kesme kuvvetleri ve yap1 ağırlıkları üzerinden incelenmiştir. $\mathrm{Bu}$ incelemede yatayda 3 ve düşey doğrultuda 4 akslı $8 \mathrm{~m} \times 14 \mathrm{~m}$ boyutunda simetrik bir yapı seçilmiştir (Şekil 1). Yap1 bodrum, zemin ve 4 normal kattan oluşmaktadır. Kat yükseklikleri 3'er metredir. Malzeme olarak C25 ve S420 seçilmiştir. Yap1 olarak 2. deprem bölgesinde konut, taşıyıcı sistem olarak ise süneklik düzeyi yüksek çerçeve ve duvar yükü olarak ta $18 \mathrm{~cm}$ kalınlığında gaz beton (sıva dahil 3,261 kN/m) seçilmiştir. Son katta ise duvar yükü alınmamıştır. Yer altı zemin sınıfı Z2 alınmıştır. 


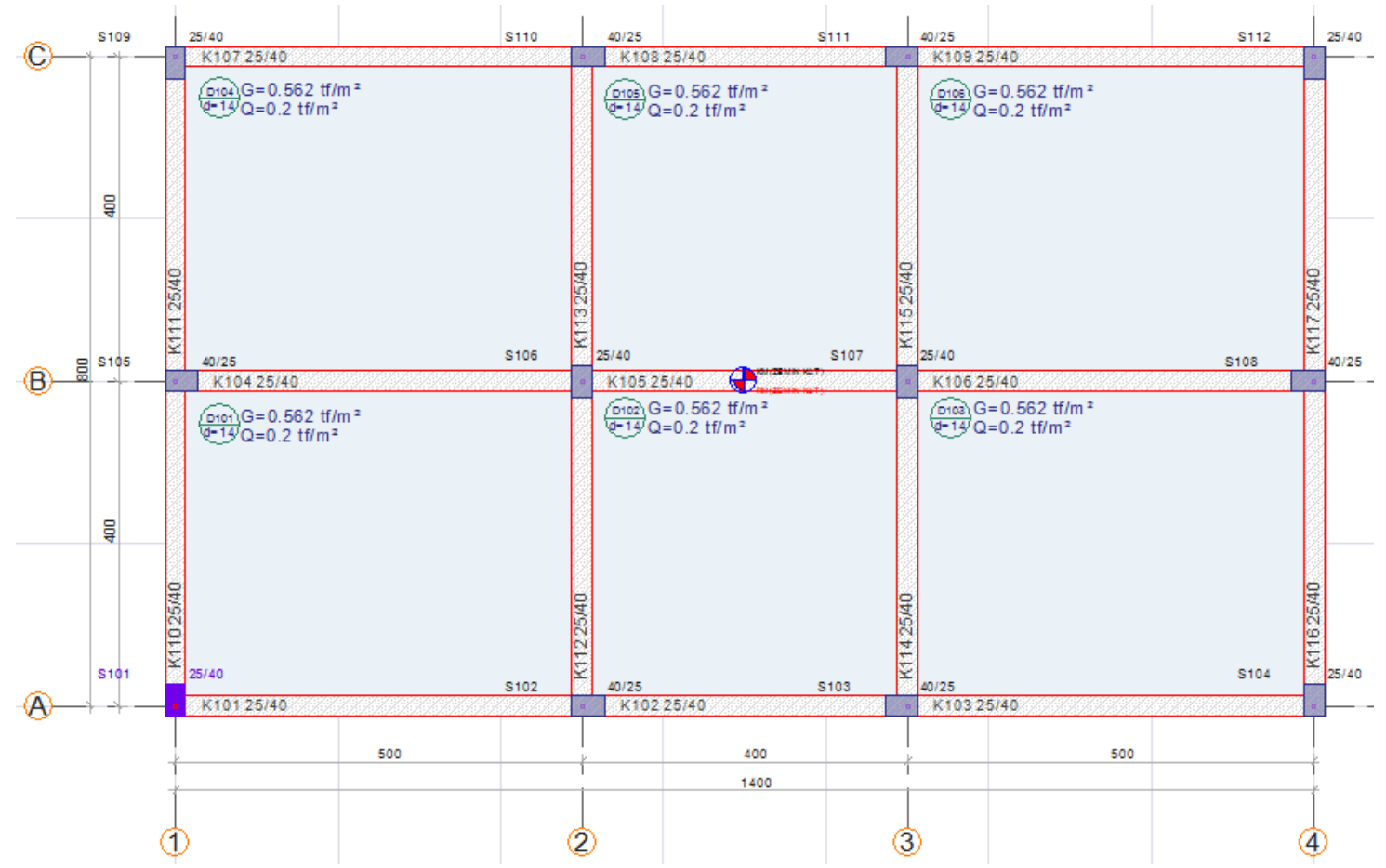

Şekil 1. Yapının kalıp planı ve üç boyutlu gösterimi

$\mathrm{Z} 2$ için $\mathrm{T}_{\mathrm{a}}=0,15$ ve $\mathrm{T}_{\mathrm{b}}=0,40$ 'dır. Yapıların analizinde İdeCAD programı kullanılmıştır. İlkönce $25 \mathrm{~cm} \times 40 \mathrm{~cm}$ boyutlarında kolonlardan oluşan simetrik yerleştirilmiş ve her iki doğrultuda atalet momentleri toplamı aynı olan bir taşıyıcı sistem seçilmiş, analiz edilmiş ve bu durum düzenli durum olarak adlandırılmıştır.
Daha sonra farklı burulma oluşma durumlarını gösterebilmek için A1 akslarının birleşim noktasındaki S1 kolonunun boyutları sirasiyla 25 $\mathrm{cm} \times 60 \mathrm{~cm}, 25 \mathrm{~cm} \times 80 \mathrm{~cm}, 25 \mathrm{~cm} \times 100 \mathrm{~cm}, 25$ $\mathrm{cm} \times 120 \mathrm{~cm}, 25 \mathrm{~cm} \times 140 \mathrm{~cm}, 25 \mathrm{~cm} \times 160 \mathrm{~cm}$ ve $25 \mathrm{~cm} \times 180 \mathrm{~cm}$ değiştirilerek analizler tekrarlanmıştır (Çizelge 1, 2).

Çizelge 1. x doğrultusu A1 burulma düzensizlikleri

\begin{tabular}{|c|c|c|c|c|c|c|c|c|c|c|c|c|c|c|c|c|}
\hline \multirow[b]{2}{*}{ KAT } & \multicolumn{2}{|c|}{$\begin{array}{l}\text { DÜZENLİ } \\
\text { DURUM }\end{array}$} & \multicolumn{2}{|c|}{$25 * 60$} & \multicolumn{2}{|c|}{$25 * 80$} & \multicolumn{2}{|c|}{$25 * 100$} & \multicolumn{2}{|c|}{$25 * 120$} & \multicolumn{2}{|c|}{$25 * 140$} & \multicolumn{2}{|c|}{$25 * 160$} & \multicolumn{2}{|c|}{$25 * 180$} \\
\hline & $\begin{array}{l}(+) \\
\% 5 \\
\end{array}$ & $\begin{array}{l}-) \\
\% 5 \\
\end{array}$ & $\begin{array}{l}(+) \\
\% 5\end{array}$ & $\begin{array}{l}(-) \\
\% 5\end{array}$ & & $\begin{array}{l}(-) \\
\% 5\end{array}$ & $(+)$ & $\begin{array}{l}(-) \\
\% 5\end{array}$ & $\begin{array}{l}(+) \\
\% 5\end{array}$ & $\begin{array}{l}(-) \\
\% 5\end{array}$ & $\begin{array}{l}(+) \\
\% 5\end{array}$ & $\begin{array}{l}(-) \\
\% 5\end{array}$ & & $\begin{array}{l}(-) \\
\% 5\end{array}$ & $\begin{array}{l}(+) \\
\% 5\end{array}$ & $\begin{array}{l}(-) \\
\% 5\end{array}$ \\
\hline 4. & 1,04 & 1,04 & 1,05 & 1,04 & 1,04 & 1,03 & 1,04 & 1,03 & 1,04 & 1,03 & 1,05 & 1,03 & 1,05 & 1,02 & 1,05 & 1,02 \\
\hline 3. & 1,04 & 1,04 & 1,05 & 1,04 & 1,04 & 1,02 & 1,04 & 1,02 & 1,04 & 1,02 & 1,04 & 1,02 & 1,04 & 1,02 & 1,04 & 1,02 \\
\hline 2. & 1,04 & 1,04 & 1,05 & 1,04 & 1,04 & 1,02 & 1,04 & 1,02 & 1,04 & 1,02 & 1,04 & 1,02 & 1,04 & 1,02 & 1,04 & 1,02 \\
\hline 1. & 1,04 & 1,04 & 1,05 & 1,04 & 1,04 & 1,02 & 1,04 & 1,02 & 1,04 & 1,02 & 1,04 & 1,02 & 1,04 & 1,01 & 1,04 & 1,01 \\
\hline 2 & 1,04 & 1,04 & 1,05 & 1,04 & 1,04 & 1,02 & 1,04 & 1,02 & 1,04 & 1,02 & 1,03 & 1,01 & 1,03 & 1,01 & 1,03 & 1,01 \\
\hline $\mathrm{D}$ & 1,04 & 1,04 & 1,04 & 1,03 & 1,03 & 1,01 & 1,03 & 1,01 & 1,03 & 1,01 & 1,03 & 1,01 & 1,04 & 1 & 1,04 & 1 \\
\hline
\end{tabular}


Çizelge 2. y doğrultusu A1 burulma düzensizlikleri

\begin{tabular}{|c|c|c|c|c|c|c|c|c|c|c|c|c|c|c|c|c|}
\hline \multirow[b]{2}{*}{ KAT } & \multicolumn{2}{|c|}{$\begin{array}{l}\text { DÜZENLİ } \\
\text { DURUM }\end{array}$} & \multicolumn{2}{|c|}{$25 * 60$} & \multicolumn{2}{|c|}{$25 * 80$} & \multicolumn{2}{|c|}{$25 * 100$} & \multicolumn{2}{|c|}{$25 * 120$} & \multicolumn{2}{|c|}{$25 * 140$} & \multicolumn{2}{|c|}{$25 * 160$} & \multicolumn{2}{|c|}{$25 * 180$} \\
\hline & \begin{tabular}{l|}
$(+)$ \\
$\% 5$ \\
\end{tabular} & $\begin{array}{l}(-) \\
\% 5 \\
\end{array}$ & $\begin{array}{l}(+) \\
\% 5 \\
\end{array}$ & $\begin{array}{l}(-) \\
\% 5 \\
\end{array}$ & $\begin{array}{l}(+) \\
\% 5 \\
\end{array}$ & $\begin{array}{l}(-) \\
\% 5 \\
\end{array}$ & $\begin{array}{l}(+) \\
\% 5 \\
\end{array}$ & $\begin{array}{l}(-) \\
\% 5 \\
\end{array}$ & & $\begin{array}{l}-) \\
\% 5 \\
\end{array}$ & $\begin{array}{l}(+) \\
\% 5\end{array}$ & $\begin{array}{l}(-) \\
\% 5 \\
\end{array}$ & & $\begin{array}{l}(-) \\
\% 5 \\
\end{array}$ & $\begin{array}{l}(+) \\
\% 5 \\
\end{array}$ & $\begin{array}{l}(-) \\
\% 5 \\
\end{array}$ \\
\hline 4. & 1,11 & 1,11 & 1,1 & 112 & 1,12 & 1,1 & 15 & 1 & 1,17 & 1,06 & 1,18 & 1,04 & 1,18 & 1,05 & 1,17 & 1,06 \\
\hline 3. & 1,12 & 1,12 & 1,08 & 1,16 & 1,06 & 1,18 & 1,04 & 1,19 & 1,02 & 1,21 & 1 & 1,23 & 1,03 & 1,25 & 1,06 & 1,28 \\
\hline 2. & 1,12 & 1,12 & 1,08 & & 1,05 & 1,19 & 1,02 & 1,21 & 1,01 & 1,21 & 1,06 & 1,28 & 1,11 & 1,33 & 1,16 & 1,37 \\
\hline 1. & 1,13 & 1,13 & 1,09 & 1,16 & 1,06 & 1,19 & 1,01 & 1,22 & 1,04 & 1,27 & 1,1 & 1,33 & 1,17 & 1,38 & 1,24 & 1,44 \\
\hline $\mathrm{Z}$ & 1,13 & 1,13 & 1,09 & 1,16 & 1,03 & 1,21 & 1,05 & 1,28 & 1,13 & 1,35 & 1,22 & 1,43 & 1,3 & 1,49 & 1,38 & 1,56 \\
\hline B & 1,13 & 1,13 & 1,02 & 1,26 & 1,17 & 1,39 & 1,3 & 1,49 & 1,41 & 1,58 & 1,5 & 1,65 & 1,58 & 1,71 & 1,64 & 1,76 \\
\hline
\end{tabular}

Çizelge 1 ve 2'de aynı yapıya ait sekiz farklı taşıyıcı sistem için kütle merkezlerine $(+\% 5)$ ve $(-\% 5)$ eksantrisite eklenmesi durumlarına ait her kat için elde edilen $\mathrm{x}$ ve $\mathrm{y}$ doğrultularına ait burulma düzensizlikleri verilmiştir. Kolon boyutunun y doğrultusunda büyütülmesi ve bunun sonucu olarak eksantrisitenin oluşmasıyla öncelikle en alt katlardan başlamak üzere burulma düzensizliklerinin oluştuğu gözlenmiştir. Şekil 2'de sekizinci durum olan A1 kolonunun $25^{*} 180$ seçilmesi için bodrum katta eksantrisitenin kalıp planındaki gösterimi verilmiştir.

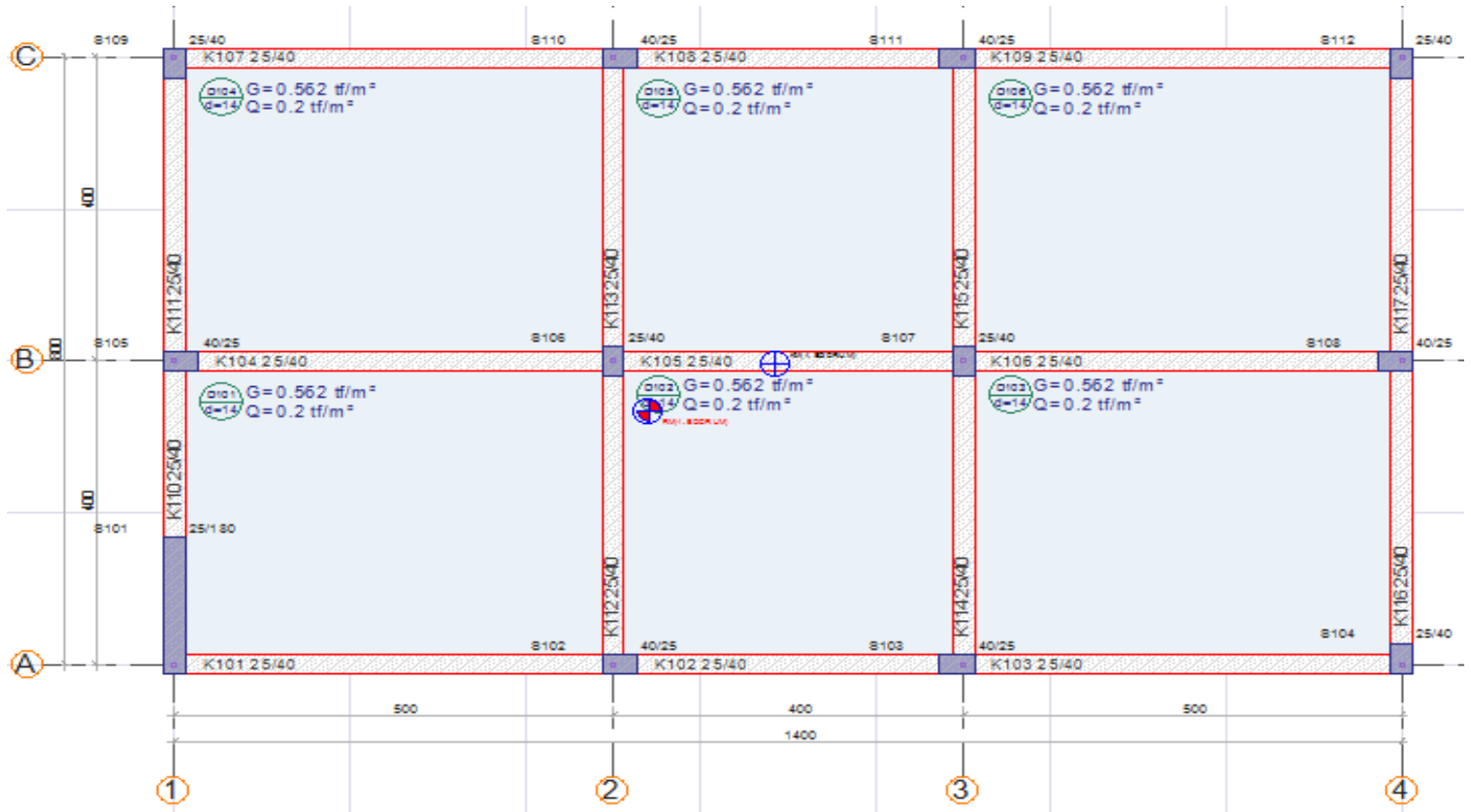

Şekil 2. Bodrum kat kalıp planında kütle ve rijitlik merkezi gösterimi 


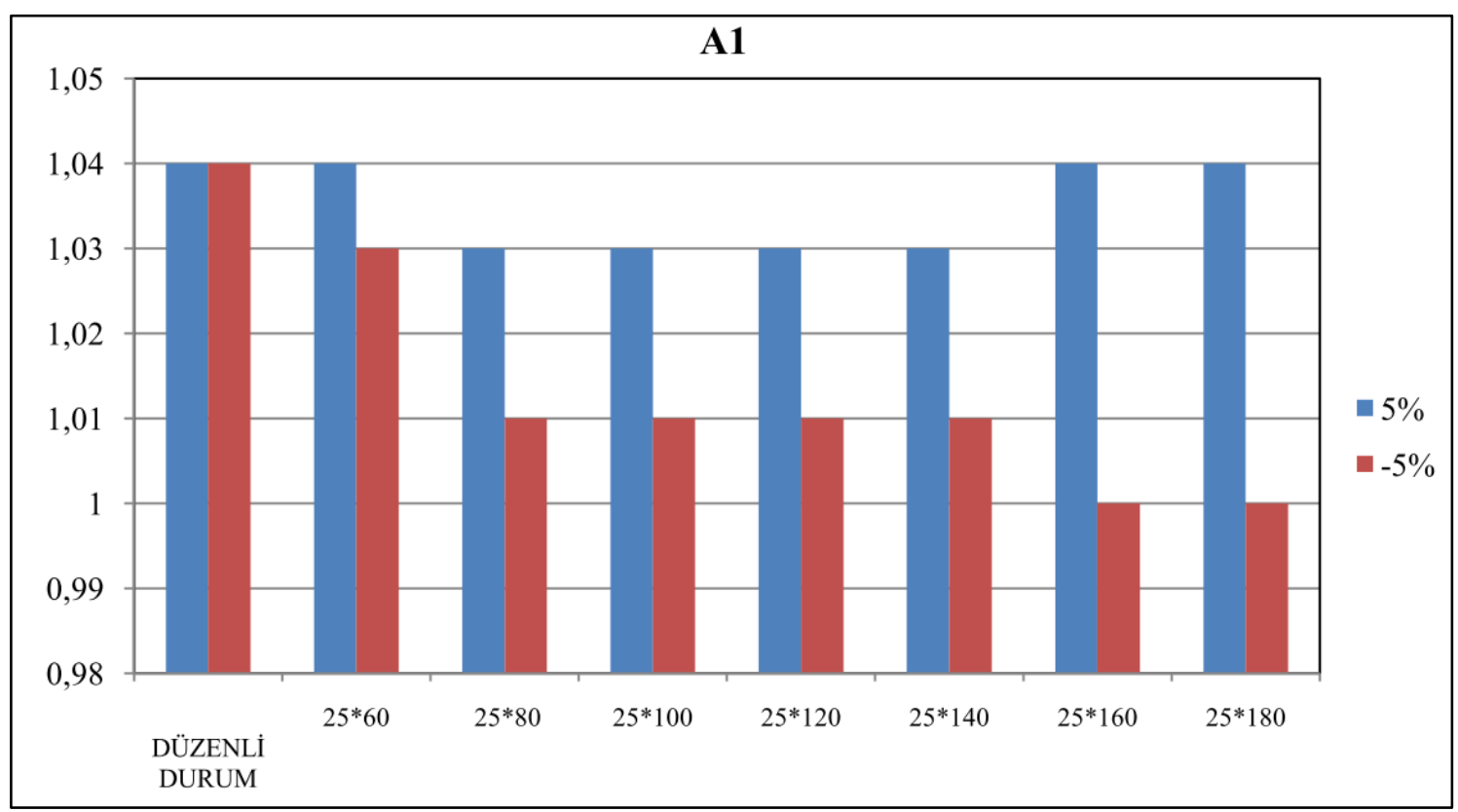

Şekil 3. Bodrum katta x doğrultusunda burulma düzensizliği

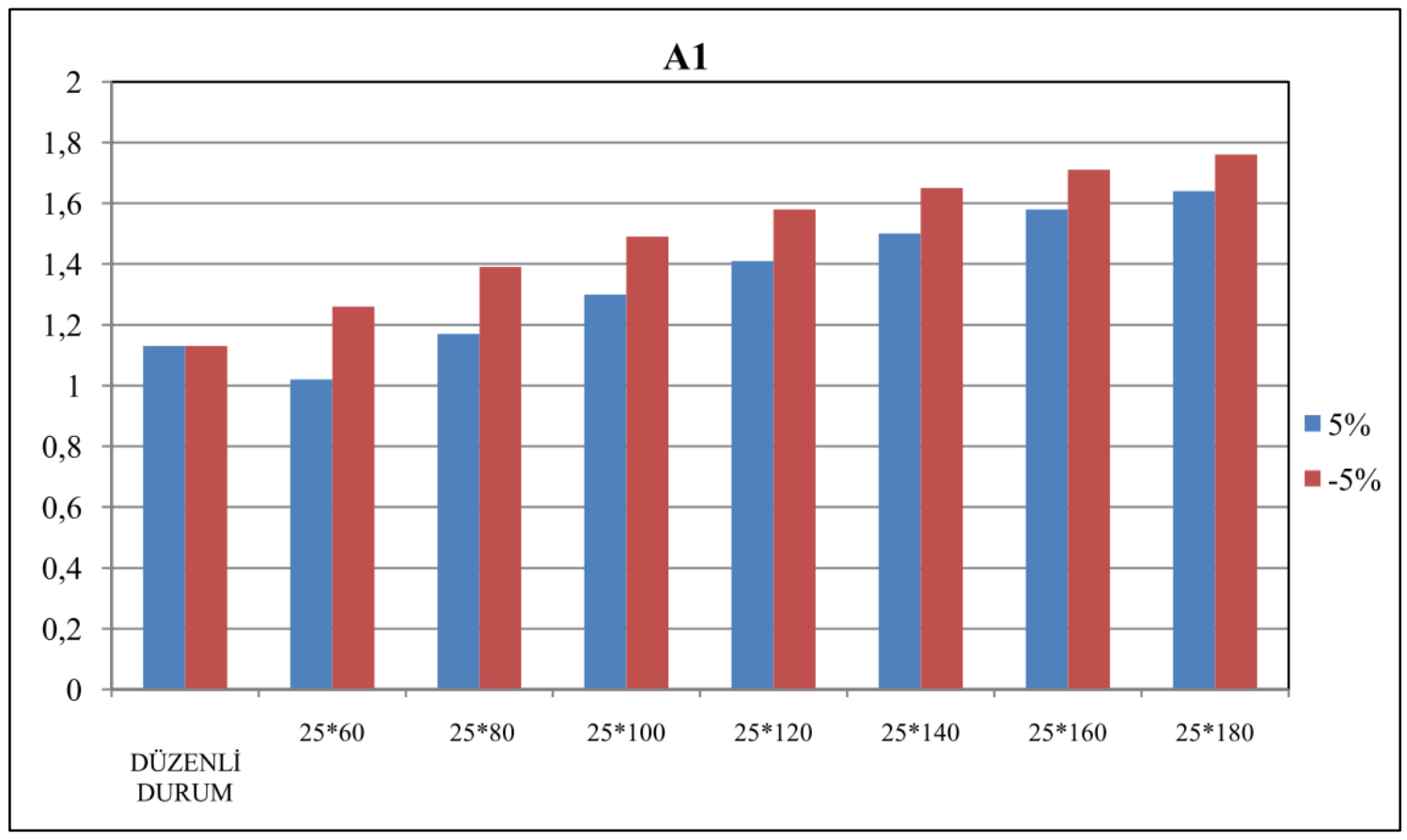

Şekil 4. Bodrum katta y doğrultusunda burulma düzensizliği 
Şekil 3'de bodrum katlar için x doğrultusunda deprem yüklemesi durumu için burulma düzensizlikleri verilmiş ve grafikten $(-\% 5)$ için burulma düzensizliğinin azaldığı görülmektedir. Diğer durum için ise burulma düzensizliğinin değişimi az olmuştur. Şekil 4'de ise bodrum katlar için y doğrultusunda deprem yüklemesi durumu için burulma düzensizlikleri verilmiş ve grafikten hem $(+\% 5)$ hem de $(-\% 5)$ için burulma düzensizliklerinin arttığı görülmüştür.
Bu grafikten (-\%5) için artışın biraz daha fazla olduğu anlaşılmaktadır. İncelenen yapının kalıp planında boşluklar, döşeme kalınlığı değişimleri olmadığından A2 döşeme süreksizlikleri düzensizliği yoktur. Ayrıca yine kalıp planında çıkıntılar olmadığından A3 planda çıkıntı bulunması düzensizliği de bulunmamaktadır. Yap1 ağırlığı $\mathrm{W}$ kolon büyüklüklerinin büyümesine bağlı olarak da artmaktadır (Şekil 5).

Çizelge 3. B2 düzensizlikleri (+\%5 ve $-\% 5$ için her katta maksimum değerler)

\begin{tabular}{|c|c|c|c|c|c|c|c|c|}
\hline Katlar & $\begin{array}{l}\text { Düzenli } \\
\text { Durum }\end{array}$ & $25 * 60$ & $25 * 80$ & $25 * 100$ & $25 * 120$ & $25 * 140$ & $25 * 160$ & $25 * 180$ \\
\hline 4. & 0,57 & 0,58 & 0,6 & 0,63 & 0,65 & 0,67 & 0,69 & 0,7 \\
\hline 3. & 1,88 & 1,88 & 1,88 & 1,88 & 1,87 & 1,87 & 1,87 & 1,86 \\
\hline 2. & 1,39 & 1,39 & 1,39 & 1,39 & 1,39 & 1,39 & 1,39 & 1,39 \\
\hline 1. & 1,23 & 1,23 & 1,23 & 1,23 & 1,23 & 1,23 & 1,23 & 1,23 \\
\hline Z & 1,21 & 1,21 & 1,21 & 1,22 & 1,22 & 1,22 & 1,22 & 1,22 \\
\hline B & - & - & - & - & - & - & - & - \\
\hline
\end{tabular}

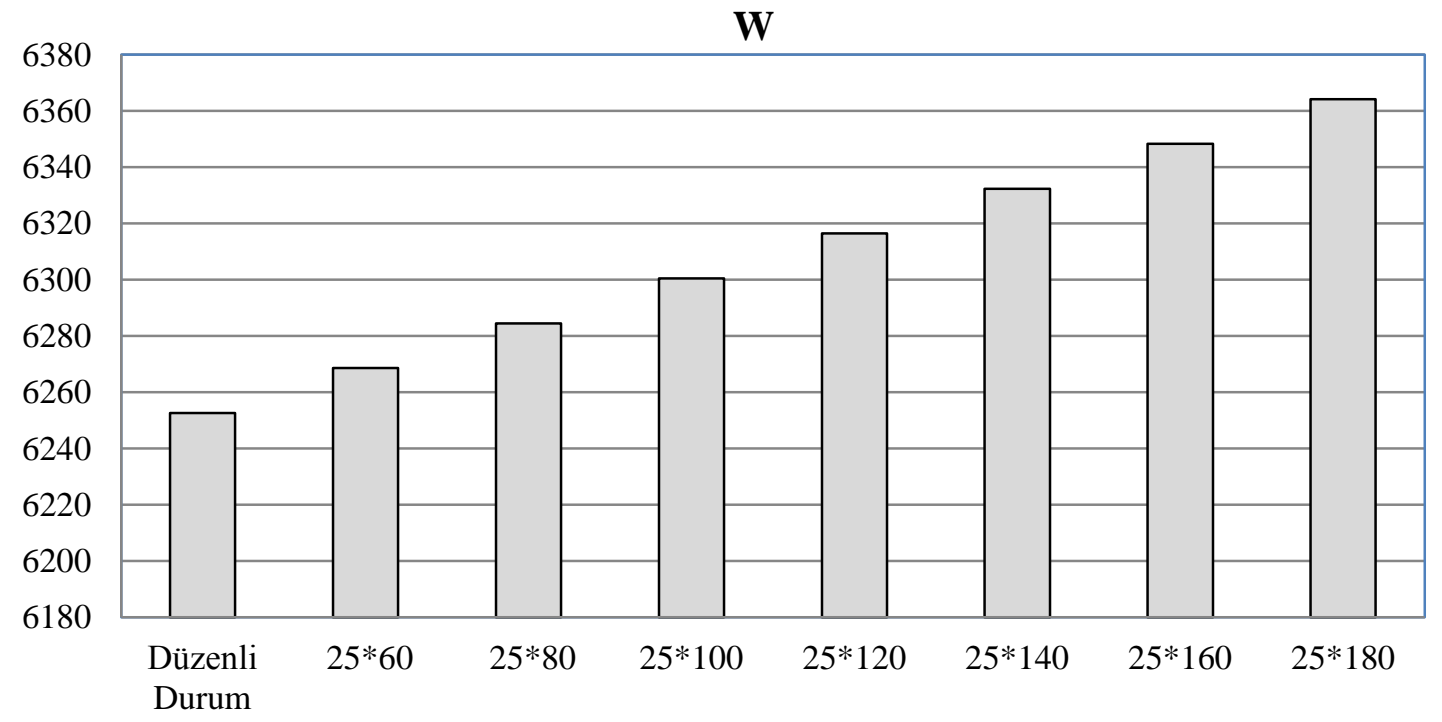

Şekil 5. Hareketli yükler dahil toplam yapı ağırlı̆̆ı $(\mathrm{kN})$ 

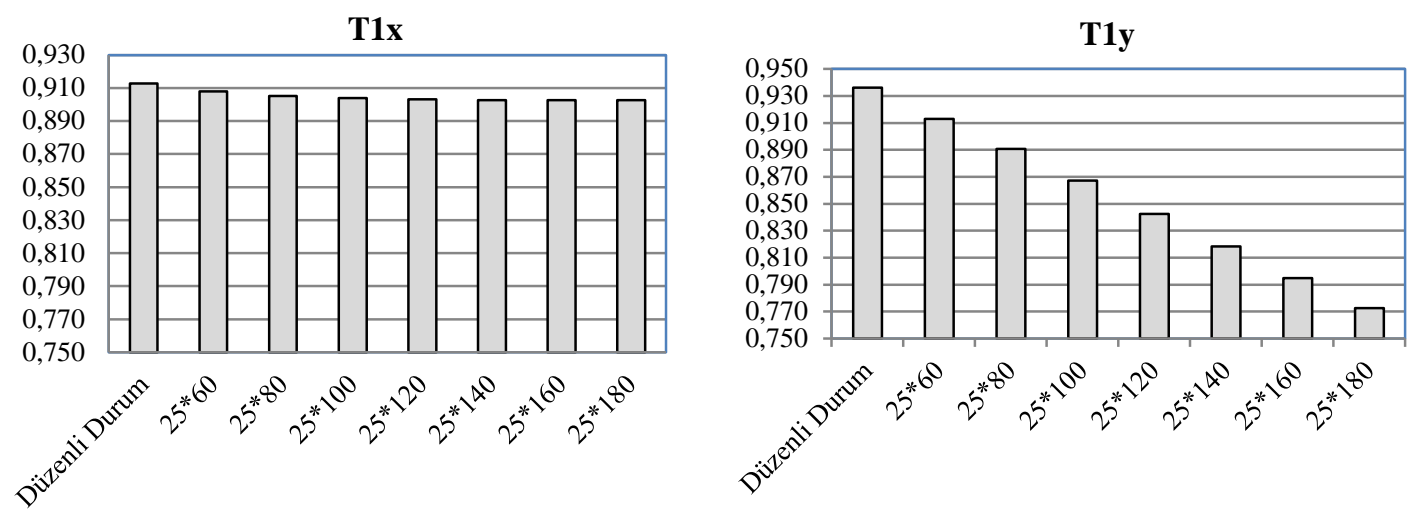

Şekil 6. $x$ ve y doğrultularında birinci doğal titreşim periyotları (sn)
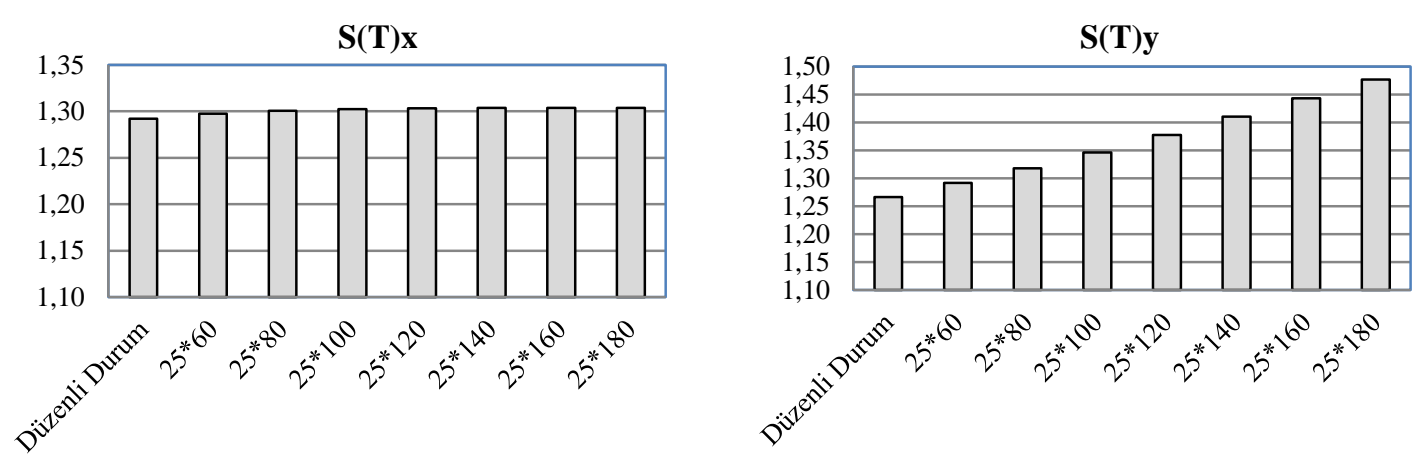

Şekil 7. x ve y doğrultularında spektrum katsayıları
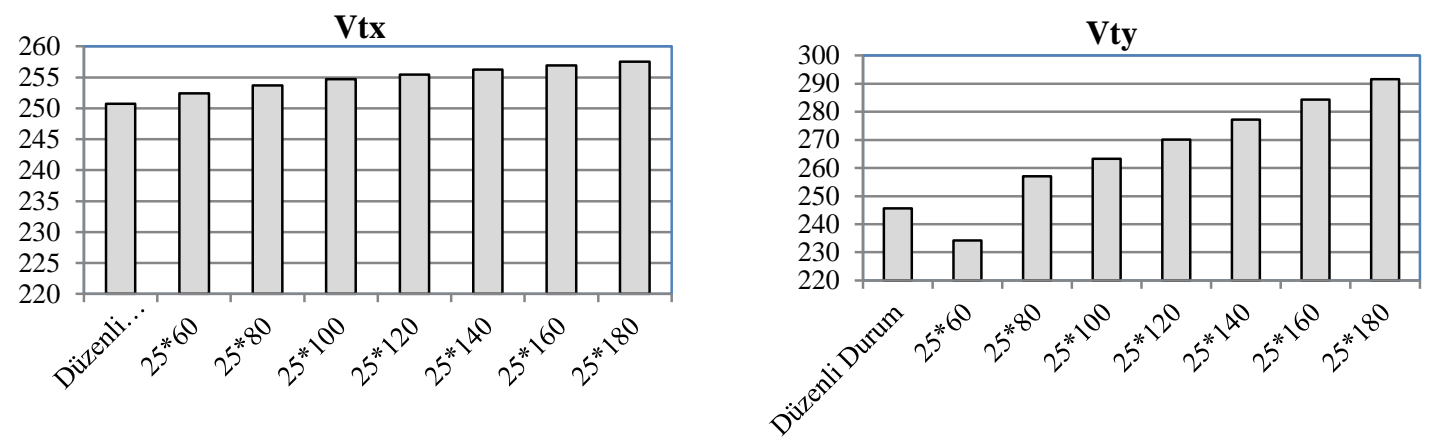

Şekil 8. $x$ ve y doğrultularında toplam eşdeğer deprem kuvvetleri $(\mathrm{kN})$ 
Hesaplarda, $T_{1 x}$ ve $T_{1 y}$ değerleri $T_{b}=0,40$ dan büyük hesaplanmıştır (Şekil 6). Bu durumda spektrum katsayıs1 hesabinda $\mathrm{S}(\mathrm{T})=2,5\left(\mathrm{~T}_{\mathrm{b}} / \mathrm{T}\right)^{0,8}$ kullanılması gerekir. $\mathrm{T}_{1 \mathrm{x}}$ deki azalmadaki değişim az olduğundan $\mathrm{S}(\mathrm{T})_{\mathrm{x}}$ daha az artmakta, $\mathrm{T}_{1 \mathrm{y}}$ deki azalma ise belirgin fazla olduğundan $S(T)_{y}$ daha fazla artmaktadır (Şekil 7). Yapı ağırlığı ve spektrum katsayısı taban kesme kuvvetini artırır. Yap1 ağırlığı $\mathrm{x} \quad$ ve $\mathrm{y}$ doğrultularında aynı alınacağından taban kesme kuvvetini spektrum katsayısı belirler. $\mathrm{X}$ doğrultusu için spektrum katsayısındaki değişim az artış olacağından $\mathrm{V}_{\mathrm{tx}}$ 'in değeri birinci ve sekizinci durum arasında az değişir (Şekil 8). Y doğrultusunda ise spektrum katsayısı birinci ve sekizinci durum arasında belirgin olarak arttığından buna bağlı olarak $\mathrm{V}_{\text {ty }}$ 'de belirgin bir artış yaşanmıştır (Şekil 8).

\section{SONUÇLAR}

Deprem bölgelerinde yapılacak binalar hakkında yönetmelikte, yapıların taşıyıcı sistemlerinin yüklemeler altında olumlu bir davranış gösterebilmesi için, planda ve düşey doğrultuda düzensizlikler oluşmayacak biçimde tasarlanması istenmektedir. Yönetmelik burulma düzensizliğinden mümkün olduğunca kaçınılması gerektiğini belirtmektedir. Bu çalışmada burulma düzensizliği olmayacak /oluşabilecek şekilde aynı yapı için sekiz farklı taşıyıcı sistem oluşturulmuş ve İdeCAD programı ile yapılar analiz edilmiştir. Öncelikle düzensizlikler, sonra ise yapı ağırlığg, birinci periyotlar, spektrum katsayıları ve deprem nedeniyle oluşacak taban kesme kuvvetleri ve bunların seçilen taşıyıcı sistem seçimine göre değişimleri incelenmiştir. Elde edilen sonuçlardan kütle ve rijitlik merkezlerinin çakıștırılmaması durumlarında burulma düzensizliklerinin oluşacağ1, kolon boyutlarının büyütülmesi ile yapının kolon boyutlarının büyütüldüğü doğrultuda rijitliğinin $\operatorname{artt1ğ} 1$, rijitliğin $\operatorname{arttığ} 1$ doğrultuda spektrum katsayısının büyüdüğü ve taban kesme kuvvetinin de bu doğrultuda arttığ1 gözlenmiştir. Komşu katlar arası rijitlik düzensizliğinin burulma düzensizliğinden çok etkilenmediği görülmüştür. A2, A3, B1 ve B3 düzensizlikleri taşıyıcı sistem seçiminden dolayı oluşmamıştır. Sonuç olarak elde edilen sonuçlardan yapının kolonlarının yerleşimlerine göre yapıda burulmalar oluşacağı, yapının her iki doğrultuda rijitliklerine bağlı olarak yapının peryotlarının ve taban kesme kuvvetlerinin değişeceği gösterilmiştir. Taban kesme kuvvetine bağlı olarak ta taşıyıcı sistemi oluşturan elemanlarda kuvvetlerde bir artış gözleneceğinden, yapının analiz sonuçlarının olumlu etkilenmesi için burulma düzensizliği oluşmayacak taşıyıcı sistem seçimine özen gösterilmesi gerekmektedir.

\section{KAYNAKLAR}

1. Deprem Bölgelerinde Yapılacak Binalar Hakkında Yönetmelik, 2007.Bayındırlık ve İskan Bakanlığı, Mart, Ankara.

2. Boğa, H., 2000. Çok Katlı Betonarme Yapılarda Burulma Düzensizliğinin İrdelenmesi, Yüksek Lisans Tez Çalışması, Balıkesir Üniversitesi Fen Bilimleri Enstitüsü, İstanbul.

3. Özmen, G., 2001. Çok Katlı Yapılarda Burulma Düzensizliği, Teknik Rapor No: TDV/TR 036-61, Türkiye Deprem Vakfi, İstanbul.

4. Özmen, G., 2001. Rijitlik Dağılımının Burulma Düzensizliğine Etkisi, Türkiye Mühendislik Haberleri Dergisi, 411/1, 37-40.

5. Özmen, G., 2004. Çok Katlı Yapılarda Aşırı Burulma Düzensizliği, İnşaat Mühendisleri Odası Teknik Dergi, 3131-3144.

6. Özmen, G., 2011. Deprem Yönetmeliklerindeki Burulma Düzensizliği Koşullarının İrdelenmesi, Teknik Rapor No: TDV/TR 05391, Türkiye Deprem Vakfı, İstanbul.

7. Özmen, G., 2012. Deprem Yönetmeliklerindeki Burulma Düzensizliği Koşulları, Türkiye Mühendislik Haberleri Dergisi, 472/2, 52-64.

8. Livaoğlu, R., 2001. Yapıların Deprem Hesabında Burulma Düzensizliğinin ve Hesap Yöntemlerinin Etkinliğinin İncelenmesi, Karadeniz Teknik Üniversitesi Fen Bilimleri Enstitüsü Yüksek Lisans Tezi, 145 sayfa.

9. Uçar, T., Merter, O., 2009. Planda Perde Yerleşiminin Betonarme Perde-Çerçeveli Binaların Deprem Davranışına Etkisi, Dokuz Eylül Üniversitesi Mühendislik 
Fakültesi Mühendislik Bilimleri Dergisi, 11/2, 11-18.

10. Doğan, O., Er, Ş.B., 2010. Hareketli Yük Dağılımının Burulma Düzensizliğine Etkisinin İncelenmesi, International Journal of Engineering Research and Development, 2/2.

11. Sandıkçı, T., 2014. Bina Türü Betonarme Bir Yapıda Yumuşak Kat ve Burulma Düzensizliği İlişkisinin İncelenmesi, Karadeniz Teknik Üniversitesi Fen Bilimleri Enstitüsü Yüksek Lisans Tezi, 107 sayfa. 